Pak. j. sci. ind. res. Ser. B: biol. sci. 2018 61B(3) 145-150

\title{
Fortification and Stability of Iodine in Bread to Mitigate Iodine Deficiency Disorder
}

\author{
Muhammad Sajid Manzoor ${ }^{\mathrm{a}}$, Imran Pasha ${ }^{\mathrm{a} *}$, Shabbir Ahmad ${ }^{\mathrm{b}}$, Mian Kamran Sharif and \\ Muhammad Farhan Jahangir Chughtai ${ }^{\mathrm{a}}$ \\ ${ }^{a}$ National Institute of Food Science and Technology, University of Agriculture, Faisalabad, Pakistan \\ ${ }^{b}$ Department of Food Science and Technology, Muhammad Nawaz Shareef University of Agriculture, Multan, \\ Pakistan
}

(received January 2, 2017; revised October 3, 2017; accepted October 23, 2017)

\begin{abstract}
The core objective of this study was to prepare iodized bread by using iodized salt and potassium iodide (KI) to fulfill Recommended Daily Intake (RDI) of iodine. Triplicate level of each fortificant was added in separate treatments in different concentrations with an aim that 2 slices of bread provide RDI of iodine. The prepared samples were analyzed for stability of iodine by spectrophotometric method and for sensory attributes by panel of judges. Results showed good retention of iodine in bread with 15-20\% loss of iodine in final product after processing. A slight level of potassium was increased in treatments in which KI was used while other minerals profile was not affected by fortificants and showed no significant behaviour after examining the results statistically.
\end{abstract}

Keywords: fortification, stability iodized bread, iodine deficiency

\section{Introduction}

A balanced diet is indispensable for optimal functioning, metabolism, growth and development of human body. Carbohydrate, protein, lipid, vitamin and inorganic micronutrients are prerequisite of balanced diet. Trace elements play vital role in human body as being structural component of hormones, vitamins and cofactors of enzymes (Freeland-Graves et al., 2014). Even the least deficiency of various vitamins and minerals can disturb the functioning of immune system and can cause serious diseases (Akhter et al., 2004). Minerals are classified as macro and micro minerals. Micro minerals also known as trace elements are inorganic constituents present in all tissues and fluids of human body. Minerals however do not produce the energy but are significant for many physiochemical processes required to carry out normal life processes (Soetan et al., 2010).

Iodine, trace mineral element, present in minute fraction in human body is radiologically indispensable element. In human body, thyroid gland is the main organ in which iodine is present and it has an effectual role in the production of thyroid hormones. These hormones highly influence the functioning of nerve tissues and muscles, circulatory system, intellectual physical development and heat energy regulation of body (Zimmermann, 2008). It impedes abnormal growth of bacteria in

*Author for correspondence; E-mail: ipasha2001@yahoo.com stomach and can transmute allergic proteins entering in body to non-allergic by coating them. It also deactivates most of chemical toxins, all biological poisons and spread of cancer cells to secure body from dreadful diseases and infections (Freeland-Graves et al., 2014).

Iodine is a fundamental micronutrient needed at all stages of human life but the pregnancy, fetal life and early childhood are the most important stages of requirement (Zimmermann, 2008). World Health Organization (WHO), United Nations International Children's Emergency Fund (UNICEF) and International Council for Control of Iodine Deficiency Disorder (ICCIDD) recommended that preschool children should take $90 \mu \mathrm{g}$ of iodine per day, for school children this value is $120 \mu \mathrm{g}$ per day, $150 \mu \mathrm{g}$ per day for 12 years and above while pregnant and lactating women should take $250 \mu \mathrm{g}$ of iodine per day (Longvah et al., 2013). Pregnant women have more need of iodine because of the increased synthesis of thyroid hormone, mandatory for the normal and healthy development of fetal brain and neurological network (Elahi et al., 2009).

Deficiency of iodine is the public health problem all over the globe. Amongst the ten greatest challenges to global welfare, universal salt iodization is third one suggested by the participants of Copenhagen Consensus (Horton et al., 2008). More than 1.88 billion people in 
the world have insufficient iodine level including 241 million children. People are prone to several types of risks due to iodine deficiency like neonatal hypothyroidism, endemic goiter, pregnancy loss, cretinism, infant mortality, growth retardation and intellectual impairment (Pearce et al., 2013; Andersson et al., 2012). In Pakistan, $70 \%$ people are afflicted with iodine deficiency disorder (IDD). The appalling instance of iodine deficiency in pregnant females is main reason that one third of infants in Pakistan have low birth weight (Zimmermann, 2011). During early infancy and fetal life, most drastic effect of iodine scantiness occur on the brain (IM, 2002). Hypothyroid people are less efficient and consequently, economy can be handicapped by reducing work output (Jooste and Zimmermann, 2008).

Different strategies are available and applicable to control and prevent micronutrient deficiencies including iodine deficiency disorders. Three of them are dietary diversification, supplementation and fortification for both targeted and untargeted population (Popovici et al., 2006). Food fortification means the addition of mandatory micronutrient in processed and treated foods. Food fortification is a worthwhile method reinforces the approaches used to diminish and restrain the problem of micronutrient malnutrition (WHO and FAO, 2006). Fortification of iodine is widespread to control and prevent the adverse effects of less iodine intake (Rasmussen et al., 2014). Sodium and potassium iodides and iodates are recommended additives for fortification of iodine in food. Level for their addition to salt may be equivalent to $25-65 \mathrm{mg}$ iodine per $\mathrm{kg}$ salt (Thomson, 2009). Iodized salt also has been proven an excellent and effective mean for iodine fortification in many industrialized countries (De Benoist et al., 2004). Iodized salt is used in breads, biscuits and breakfast cereals due to higher consumption of bakery products (Thomson, 2009).

Bread is an important source having vital diet components that may include iodized salt. Fortified bread not only provides nutritional minerals to our cells, but it has potential to dissolve, sanitize and clean toxic wastes from our body system. Salt is one of the few perfect fortificants for micronutrient fortification because it is among those foods that are globally consumed on regular bases at a fairly constant rate by almost all sections of a population regardless of their economic and social status (Zimmermann and Boelaert, 2015). Fortification of bread with iodine to combat iodine deficiency disorders and to determine processing effect on iodine stability were main objectives in this research.

\section{Materials and Methods}

Procurement of raw material. Wheat variety i.e. "Faisalabad 2008" for bread making was selected and procured from Ayub Agricultural Research Institute, Faisalabad. Chemicals and reagents were procured from Sigma Aldrich.

Chemical evaluation of wheat flour. Wheat flour was evaluated for chemical composition according to AACC (2000) i.e., moisture content with method No. 44-15A, crude protein with method No. 46-10, crude fat with method No. 30-10, crude fibre with method No. 32-10 and ash content with method No. 08-01. For moisture content 3-5 g sample was taken in China dish, put in hot air oven at $100 \pm 5{ }^{\circ} \mathrm{C}$ for overnight and moisture content was measured by calculating the weight loss. Wheat flour sample about 1-3 g digested with concentrated $\mathrm{H}_{2} \mathrm{SO}_{4}$ till light green colour and distilled after diluting with distilled water about $250 \mathrm{~mL}$ total volume. After distillation, the resultant solution of ammonium borate was titrated with $0.1 \mathrm{~N} \mathrm{H}_{2} \mathrm{SO}_{4}$. This method gives the estimation of total nitrogen which was converted to protein by multiplying with 5.7 factor.

For fat determination, 10-15 g sample was wrapped in filter paper and washed with petroleum ether in Soxhlet apparatus. At the end, fat free sample was placed in hot air oven at $100 \pm 5{ }^{\circ} \mathrm{C}$ for overnight and fat content was measured by calculating the weight loss. Fat and moisture free sample (1-3 g) was digested with $1.25 \%$ solution of $\mathrm{H}_{2} \mathrm{SO}_{4}$ and after washing with $1.25 \%$ solution of $\mathrm{NaOH}$. The residues obtained after washing and filtration were charred and placed in muffle furnace at $550{ }^{\circ} \mathrm{C}$ for 5-6 $\mathrm{h}$. The fibre was calculated by measuring the difference before and after placing in muffle furnace. For ash determination, 1-2 g sample was charred on direct flame and placed in muffle furnace at $550{ }^{\circ} \mathrm{C}$ for $5-6 \mathrm{~h}$. The remaining residues were measured as total ash content of flour.

Minerals like iron $(\mathrm{Fe})$, copper $(\mathrm{Cu})$, potssium $(\mathrm{K})$, zinc $(\mathrm{Zn})$ and manganese $(\mathrm{Mn})$ in flour was analyzed using Atomic Absorption Spectrophotomer (Varian AA240) as described in AOAC (2006). Sample (1-3 g) was digested in a mixture of $\mathrm{HNO}_{3}: \mathrm{HCLO}_{4}$ with $7: 3$ over hot plate. After digestion, sample was diluted with distilled water to make total volume $250 \mathrm{~mL}$. Afterwards, sample were run on atomic absorption spectrophotometer. 
Product development. For bread, a control and test runs with iodized salt and potassium iodide (source of iodine) were manufactured in the normal way in baking hall of National Institute of Food Science and Technology. Triplicate samples were prepared with each of the treatment as mentioned in Table 1. The breads were prepared according to the AACC (2000) straight dough method No 10-10B. The ingredients were mixed for 5-10 min in a Hobart A-200 mixer to form dough, afterwards the dough was molded, panned into $100 \mathrm{~g}$ pans, and proofed for $45 \mathrm{~min}$ at $95^{\circ} \mathrm{F}\left(35^{\circ} \mathrm{C}\right)$ and $85 \%$ R.H in proofer. The dough was baked at $220{ }^{\circ} \mathrm{C}$ for $22-$ $25 \mathrm{~min}$ and sliced after cooling. The bread slices were packed properly in polythene bags stored under ambient conditions and were analyzed afterwards.

Analysis of product. Chemical composition of bread. Moisture, crude protein and crude fat content of bread were analyzed by AACC (2000) methods as mentioned above. Minerals like $\mathrm{Fe}, \mathrm{Cu}$ and $\mathrm{Zn}$ of bread were analyzed using Atomic Absorption Spectrophotometer (Varian AA240) as described in AOAC (2006).

Iodine content. All bread samples were analyzed for iodine content in triplicate by a spectrophotometric method according to Moxon and Dixon (1980). Bread samples $(1 \mathrm{~g})$ of each were taken in porcelain crucible, $2 \mathrm{~mL}$ of $1 \mathrm{M}$ potassium hydroxide solution and $1 \mathrm{~mL}$ of $10 \%$ of zinc sulphate solution was added. Mixture was drived, completely on hot plate and the crucible was placed in muffle furnace at $450^{\circ} \mathrm{C}$ for $1.5 \mathrm{~h}$. The residue was dampened with zinc sulphate solution then again placed in furnace under same conditions. Subsequently, the cooled ash was transferred to centrifuge tube with $50 \mathrm{mLs}$ of deionized (DI) water. The samples were then mixed with $0.4 \mathrm{~mL}$ of $0.006 \mathrm{M}$ potassium thiocyanate solution and $1.6 \mathrm{~mL}$ of $0.2 \mathrm{M}$ ammonium iron (III) sulphate. At exactly 90 second intervals, $1 \mathrm{~mL}$ of $0.3 \mathrm{M}$ sodium nitrite solution was added. The absorbance of

Table 1. Treatment plan for iodine fortification in bread

\begin{tabular}{ll}
\hline \hline Treatment & $\begin{array}{l}\text { Iodized salt \& potassium } \\
\text { iodide }(\mathrm{KI}) / 100 \mathrm{~g}\end{array}$ \\
\hline $\mathrm{T}_{0}$ & Control \\
$\mathrm{T}_{1}$ & $1 \mathrm{~g}$ iodized salt \\
$\mathrm{T}_{2}$ & $2 \mathrm{~g}$ iodized salt \\
$\mathrm{T}_{3}$ & $3 \mathrm{~g}$ iodized salt \\
$\mathrm{T}_{4}$ & $0.546 \mathrm{mg}(546 \mu \mathrm{g}) \mathrm{KI}$ \\
$\mathrm{T}_{5}$ & $0.818 \mathrm{mg}(818 \mu \mathrm{g}) \mathrm{KI}$ \\
$\mathrm{T}_{6}$ & $1.090 \mathrm{mg}(1090 \mu \mathrm{g}) \mathrm{KI}$ \\
\hline \hline
\end{tabular}

mixture was measured at $450 \mathrm{~nm}$ after $20 \mathrm{~min}$ incubation. Iodine content was calculated using $\mathrm{KI}$ as a standard.

Sensory evaluation. The bread was prepared as above and subjected for sensory evaluation for appearance, colour, texture, flavor and taste by hedonic score system as described by Lawless and Heymann (2010). For sensory evaluation of bread, 20 panelists were selected covering faculties from teaching, research and extension wings. Panelists were of 24-40 years age with sound health and good sensory perceptions. The evaluation was carried out in a well-ventilated, odourless, and quiet environment.

Statistical analysis. The data obtained for each parameter was subjected to statistical analysis to determine the level of significance among the treatments and further values were finalized by applying means separation (Tukey-HSD) using SPSS (Statistical Package for the Social Sciences, version 10.0.1, 1999) according to the method described by Montgomery (2008).

\section{Results and Discussion}

Chemical composition of wheat flour. Chemical composition of wheat flour is shown in Table 2 and the proximate analysis of wheat flour shows average results. Moisture content of wheat flour was $9.73 \%$, protein was $10.54 \%$ and fat content of flour was $1.37 \%$. Fibre and ash contents were $2.33 \%$ and $1.67 \%$, respectively. Flour sample contain $\mathrm{Fe}, \mathrm{Zn}, \mathrm{Mn}$ and $\mathrm{Cu}$ as $1.27 \mathrm{mg}$ / $100 \mathrm{~g}, 0.82 \mathrm{mg} / 100 \mathrm{~g}, 0.80 \mathrm{mg} / 100 \mathrm{~g}$ and $0.24 \mathrm{mg} / 100 \mathrm{~g}$, respectively. The finding of the current study is congruent to the finding of Ahmad (2017); Pasha et al. (2009); and Zahoor (2003) who reported that values of moisture, protein, fat, fibre and ash were in the range of 8.92 to $11.68 \%, 10$ to $13.4 \%, 1.09$ to $2.52 \%$ and 2.20 to 2.77 $\%$, respectively in some Pakistani wheat varieties. Similar results regarding $\mathrm{Fe}, \mathrm{Zn}, \mathrm{Mn}$ and $\mathrm{Cu}$ have been obtained from the study of Khan et al. (2005) who reported that wheat flour contains $4.40 \mathrm{mg} / 100 \mathrm{~g}, 3.40$ $\mathrm{mg} / 100 \mathrm{~g}, 3.53 \mathrm{mg} / 100 \mathrm{~g}$ and $0.63 \mathrm{mg} / 100 \mathrm{~g}$ of the above mentioned minerals, respectively.

Chemical composition of bread. Bread proximate showed non-significant results revealing no effect of any treatment on the moisture, protein or fat content of bread. Baking always involves the loss of water from the 'raw' to the baked product therefore bread contains lower moisture content as compared to water added during processing (Cauvain and Young, 2000). Chemical composition of bread is presented in Table 3. In bread 
treatments, moisture content shows slight decreasing trend from $T_{0}-T_{2}$ then increases in $T_{3}$ and $T_{4}$ again decreases slightly in $\mathrm{T}_{5}$ and $\mathrm{T}_{6}$. It may be due to minor deviations in processing conditions. Protein content in bread decreased than protein content of flour and shows decreasing trend in treatments. Malomo et al. (2011) supported the results of this research, used wheat flour of $15.47 \%$ protein content and used it for bread production. After production of bread they found decreased content of protein $(11.96 \%)$ while fat increased in bread than wheat flour and shows results similar to Malomo et al. (2011). He used wheat flour of $2.60 \%$ fat content for bread production and after production of bread found increased trend of fat $(4.29 \%)$. Best treatment $\mathrm{T}_{5}$ contain moisture $30.31 \%$, protein $8.72 \%$ and fat $1.88 \%$.

Mineral analysis and their statistical behaviour showed that all of them were non-significantly affected by iodized salt and KI treatments used in bread except K content, which shows a significant result. Iron and manganese content in bread was less than previous findings of some scientists as Tuncel et al. (2014) observed $2.44 \mathrm{mg} / 100 \mathrm{~g}$ iron content in pan bread prepared with flour of wheat grain. Ragaee et al. (2006) examined $44 \mathrm{mg} / 100 \mathrm{~g}$ of iron content in wheat flour. This was due to the reason of using wheat flour for bread making that was already low in iron and manganese content. Zinc content assessed in bread was close to the previous researches as Tuncel et al. (2014) investigated $0.95 \mathrm{mg} / 100 \mathrm{~g}$ zinc content in bread prepared with wheat flour. Mean values of $\mathrm{Cu}$ in all treatments were very near about each other with highest content of $0.23 \mathrm{mg} / 100 \mathrm{~g}$ and lowest of $0.22 \mathrm{mg} / 100 \mathrm{~g}$ found randomly in different treatments showed that there was no significant effect of any treatment on content of $\mathrm{Cu}$ in bread. Level of $\mathrm{K}$ slightly raised in last 3 treatments in which KI was used as fortificant but that increase in level was only of some micrograms not exceeding its recommended intake level.

Iodine content. Iodine stability is the main issue now a days that is contradicting the struggles of iodine fortification, therefore iodine stability test was done that showed only $15-20 \%$ loss of iodine and actually depicts a high stability in terms of its need to overcome its deficiency consequences. Loss of iodine level in different treatments of bread is depicted in Table 4. Three levels of iodized salt were used in bread to prepare iodine fortified bread but iodized salt through bread supply only a little portion of required iodine because the addition of salt in bread is limited for best yeast activity and acceptable sensory characteristics. Maximum of $3 \%$ iodized salt used in bread $\left(\mathrm{T}_{3}\right)$ and after loss of iodine, two slices of that bread gave $37 \mu \mathrm{g}$ of iodine. KI in this sense gave the best result and is much effective

Table 2. Chemical composition of wheat flour

\begin{tabular}{|c|c|c|c|c|c|c|c|c|c|c|}
\hline \multirow[t]{2}{*}{ Treatments } & Moisture & Protein & Fat & Fibre & Ash & $\mathrm{Fe}$ & $\mathrm{Zn}$ & $\mathrm{Mn}$ & $\mathrm{Cu}$ & $\mathrm{K}$ \\
\hline & \multicolumn{5}{|c|}{$(\%)$} & \multicolumn{5}{|c|}{$(\mathrm{mg} / 100 \mathrm{~g})$} \\
\hline $\mathrm{R}_{1}$ & 9.9 & 10.59 & 1.33 & 2.33 & 1.68 & 1.272 & 0.824 & 0.792 & 0.234 & 96.2 \\
\hline $\mathrm{R}_{2}$ & 10.1 & 10.72 & 1.41 & 2.38 & 1.64 & 1.319 & 0.859 & 0.817 & 0.245 & 92.2 \\
\hline $\mathrm{R}_{3}$ & 9.2 & 10.33 & 1.38 & 2.29 & 1.7 & 1.221 & 0.776 & 0.779 & 0.224 & 88.4 \\
\hline Mean value & $9.73 \pm$ & $10.54 \pm$ & $1.37 \pm$ & $2.33 \pm$ & $1.67 \pm$ & $1.271 \pm$ & $0.82 \pm$ & $0.796 \pm$ & $0.234 \pm$ & $92.267 \pm$ \\
\hline & 0.472 & 0.199 & 0.404 & 0.045 & 0.031 & 0.049 & 0.042 & 0.019 & 0.011 & \\
\hline
\end{tabular}

Table 3. Chemical composition of bread

\begin{tabular}{|c|c|c|c|c|c|c|c|c|}
\hline \multirow[t]{2}{*}{ Treatments } & Moisture & Protein & Fat & Iron & Zinc & Manganese & Copper & Potassium \\
\hline & \multicolumn{4}{|c|}{$(\%)$} & \multicolumn{4}{|c|}{$(\mathrm{mg} / 100 \mathrm{~g})$} \\
\hline $\mathrm{T}_{0}$ & $30.48 \pm 0.93$ & $8.71 \pm 0.09$ & $1.87 \pm 0.09$ & $1.26 \pm 0.01$ & $0.80 \pm 0.01$ & $0.78 \pm 0.01$ & $0.23 \pm 0.01$ & $89.27 b \pm 0.85$ \\
\hline $\mathrm{T}_{1}$ & $30.14 \pm 0.96$ & $8.71 \pm 0.07$ & $1.91 \pm 0.07$ & $1.25 \pm 0.01$ & $0.81 \pm 0.02$ & $0.76 \pm 0.01$ & $0.22 \pm 0.01$ & $89.47 b \pm 0.97$ \\
\hline $\mathrm{T}_{2}$ & $29.33 \pm 0.99$ & $8.72 \pm 0.11$ & $1.87 \pm 0.08$ & $1.26 \pm 0.02$ & $0.79 \pm 0.01$ & $0.78 \pm 0.01$ & $0.23 \pm 0.02$ & $90.3 \mathrm{ab} \pm 0.91$ \\
\hline $\mathrm{T}_{3}$ & $29.84 \pm 0.99$ & $8.69 \pm 0.09$ & $1.87 \pm 0.11$ & $1.26 \pm 0.01$ & $0.81 \pm 0.02$ & $0.76 \pm 0.01$ & $0.22 \pm 0.01$ & $91.3 \mathrm{ab} \pm 0.82$ \\
\hline $\mathrm{T}_{4}$ & $30.93 \pm 0.67$ & $8.69 \pm 0.08$ & $1.9 \pm 0.08$ & $1.25 \pm 0.02$ & $0.79 \pm 0.02$ & $0.76 \pm 0.01$ & $0.23 \pm 0.01$ & $91.3 \mathrm{ab} \pm 0.83$ \\
\hline $\mathrm{T}_{5}$ & $30.31 \pm 1.11$ & $8.72 \pm 0.07$ & $1.88 \pm 0.11$ & $1.25 \pm 0.01$ & $0.80 \pm 0.01$ & $0.77 \pm 0.02$ & $0.23 \pm 0.02$ & $92.3 \mathrm{a} \pm 0.81$ \\
\hline $\mathrm{T}_{6}$ & $29.43 \pm 0.61$ & $8.68 \pm 0.09$ & $1.89 \pm 0.09$ & $1.26 \pm 0.01$ & $0.79 \pm 0.01$ & $0.76 \pm 0.01$ & $0.22 \pm 0.01$ & $92.47 \mathrm{a} \pm 0.71$ \\
\hline
\end{tabular}


Table 4. Loss of iodine level in bread

\begin{tabular}{llll}
\hline \hline $\begin{array}{l}\text { Treat- } \\
\text { ment }\end{array}$ & Iodine & $\begin{array}{l}\text { Fortificant added before } \\
\text { processing per 100g }\end{array}$ & $\begin{array}{l}\text { Iodine in bread } \\
\text { after processing } \\
(\mu \mathrm{g} / 100 \mathrm{~g})\end{array}$ \\
\hline $\mathrm{T}_{0}$ & $1.99 \mathrm{~g} \pm 0.01$ & - & \\
$\mathrm{T}_{1}$ & $30.99 \mathrm{f} \pm 0.21$ & 1g iodized salt $(40 \mu \mathrm{g} \mathrm{I})$ & 30.99 \\
$\mathrm{~T}_{2}$ & $63.12 \mathrm{e} \pm 0.02$ & 2g iodized salt $(80 \mu \mathrm{g} \mathrm{I})$ & 63.13 \\
$\mathrm{~T}_{3}$ & $91.02 \mathrm{~d} \pm 0.01$ & 3g iodized salt $(120 \mu \mathrm{g} \mathrm{I})$ & 91.02 \\
$\mathrm{~T}_{4}$ & $319.20 \mathrm{c} \pm 0.15$ & $546 \mu \mathrm{g} \mathrm{KI}(417 \mu \mathrm{g} \mathrm{I})$ & 319.20 \\
$\mathrm{~T}_{5}$ & $479.87 \mathrm{~b} \pm 0.15$ & $818 \mu \mathrm{g} \mathrm{KI}(626 \mu \mathrm{g} \mathrm{I})$ & 479.87 \\
$\mathrm{~T}_{6}$ & $651.13 \mathrm{a} \pm 0.15$ & $1090 \mu \mathrm{g} \mathrm{KI}(833 \mu \mathrm{g} \mathrm{I})$ & 651.13 \\
\hline \hline
\end{tabular}

to prepare iodized bread as $T_{5}$ bread treatment in which $0.818 \mathrm{mg} / 100 \mathrm{~g}$ KI was used, supplied $172 \mu \mathrm{g}$ of iodine/ 2 slices.

Sensory analysis. In sensory evaluation of iodine fortified bread treatments volume was not altered significantly in all treatments as shown in Fig. 1. In $\mathrm{T}_{2}$ and $\mathrm{T}_{3}$, prepared with $2 \%$ and $3 \%$ iodized salt, volume slightly decreased due to high concentration of salt. Other external bread characteristics; crust colour, symmetry of form, character of crust and evenness of bake were non-significantly affected by different treatments. Internal bread characteristics (grain, aroma, texture and mastication of bread) are non-significantly affected by fortificants added except taste. The lowest score for taste of bread was found in $\mathrm{T}_{3}$ ( $3 \%$ iodized salt). The score for taste of bread was gradually increased as the amount of KI used in bread was increased. $\mathrm{T}_{6}$ prepared with $1.09 \mathrm{mg} / 100 \mathrm{~g} \mathrm{KI}$ had maximum score of taste.

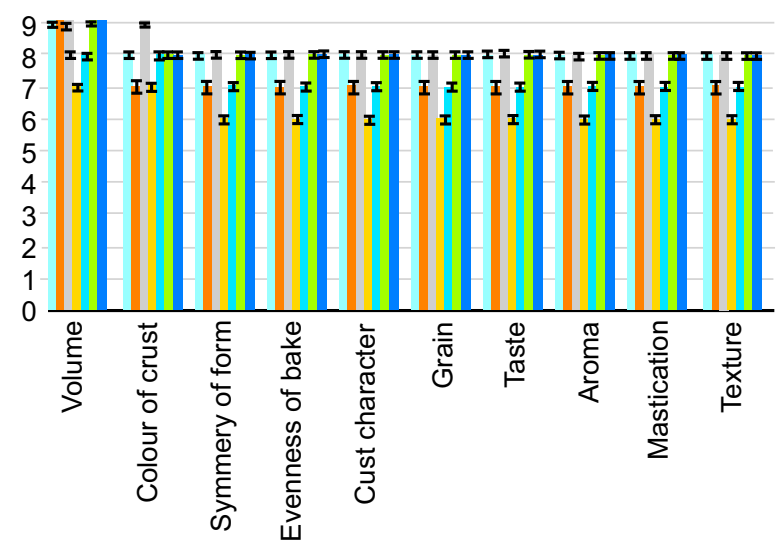

T0 $\square \mathrm{T} 1 \square \mathrm{T} 2 \square \mathrm{T} 3 \square \mathrm{T} 4 \square \mathrm{T} 5 \square \mathrm{T} 6$

$\mathrm{To}=$ Control; $\mathrm{T} 1=1 \mathrm{~g}$ iodized salt; $\mathrm{T} 2=2 \mathrm{~g}$ iodized salt; $\mathrm{T} 3=3 \mathrm{~g}$ iodized salt; T4 $=0.546 \mathrm{mg}(546 \mu \mathrm{g}) \mathrm{Kl}$; T5=0.818mg $(818 \mu \mathrm{g}) \mathrm{KI}$ and T6=1.090mg; $(1090 \mu \mathrm{g}) \mathrm{KI}$

Fig. 1. Sensory evaluation of bread

\section{Conclusion}

Bread fortified with iodized salt contained low level of iodine not enough to fulfill RDI but supports the projects working against IDD and its good practice to use iodized salt instead of non-iodized salt while KI fortified bread can alone achieve the goal to mitigate IDD. K content slightly increases in KI treatments. However, in sensory attributes only volume was affected in treatment in which 3\% iodized salt was used, so volume of bread decreases if salt concentration is increased in bread than the recommended level. Addition of KI had positive effect on taste of bread. Stability test showed 15-20\% iodine losts during processing of bread till the end of the process though it is the best means to get required iodine. Iodized salt alone would not be able to accomplish the objective but even just 2 slices of KI fortified bread provide RDI of iodine.

\section{References}

AACC, 2000. Approved Methods of the AACC. American Association of Cereal Chemists. vol. 12, 1200 pp., St. Paul, MN, USA .

Ahmad, S., Pasha, I., Saeed, M., Shahid, M. 2017. Principal component analysis and correlation studies of spring wheats in relation to cookie making quality. International Journal of Food Properties, 20: 2299-2313.

Akhter, P., Rehman, K.U., Orfi, S.D., Ahmad, N. 2004. Assessment of iodine levels in the Pakistani diet. Journal of Nutrition, 20: 783-787.

Andersson, M., Karumbunathan, V., Zimmermann, M.B. 2012. Global iodine status in 2011 and trends over the past decade. Journal of Nutrition, 142: 744-750.

AOAC, 2006. Official Methods of Analysis. $18^{\text {th }}$ edition, The Association of Official Analytical Chemists. Arlington, Gaithersburgs, MD, USA.

Cauvain, S.P., Young, L.S. 2000. The contribution of water during processing, baking, cooling and freezing. In: Bakery Food Manufacture \& Quality: Water Control \& Effects, S.P. Cauvain (ed). vol. 1, pp. $72-93,2^{\text {nd }}$ edition, Blackwell Science Limited, London, UK.

De Benoist, B., Maria, A., Ines, E., Bahi, T., Henrietta, A. 2004. Iodine status worldwide. WHO Global Database on Iodine Deficiency. World Health Organization, Geneva, Switzerland.

Elahi, S., Rizvi, N.B., Nagra, S.A. 2009. Iodine deficiency in pregnant women of Lahore. Journal 
of Pakistan Medical Association, 59: 741-743.

Freeland-Graves, J.H., Sanjeevi, N., Lee, J.J. 2015. Global perspective on trace elements requirements. Journal of Trace Elements in Medicine and Biology, 31: 135-141.

Horton, S., Mannar, V., Wesley, A. 2008. Best Practice Paper: Food Fortification with Iron and Iodine. Copenhagen Consensus Center, Copenhagen Business School, Denmark.

Jooste, P.L., Zimmermann, M.B. 2008. Progress towards eliminating iodine deficiency in South Africa. South African Journal of Clinical Nutrition, 21: 08-14.

Khan, M.I., Anjum, F.M., Hussain, S., Tariq, M.T. 2005. Effect of soy flour supplementation on mineral and phytate contents of unleavened flat bread (chapatis). Nutrition and Food Science, 35: 163-168.

Longvah, T., Toteja, G.S., Upadhyay, A. 2013. Iodine content in bread, milk and the retention of inherent iodine in commonly used Indian recipes. Food Chemistry, 136: 384-388.

Malomo, S.A., Eleyinmi, A.F., Fashakin, J.B. 2011. Chemical composition, rheological properties and bread making potentials of composite flours from breadfruit, breadnut and wheat. African Journal of Food Science, 5: 400-410.

Montgomery, D. 2008. Experiments with a single factor: The analysis of variance. In: Design and Analysis of Experiments, John Wiley \& Sons, Inc. USA.

Lawless, H.T., Heymann, H. 2010. Scaling: Sensory Evaluation of Food Principles and Practices, 171 pp. Springer Science Business Media, New York, USA.

Moxon, R.E.D., Dixon, E.J. 1980. Semi-automatic method for the determination of total iodine in food. Analyst, 105: 344-352.

Pasha, I., Anjum, F.M., Butt, M.S. 2009. Biochemical characterization of spring wheats in relation to grain hardness. International Journal of Food Properties, 12: 910-928.

Pearce, E.N., Andersson, M., Zimmermann, M.B. 2013. Global iodine nutrition: where do we stand in 2013? Thyroid, 23: 523-528.

Popovici, C., Sturza, R., Deseatnicov, O. 2006. Study of the incorporation of iodine in vegetable oils. Journal of the University of Chemical Technology and Metallurgy, 4: 449-456.

Ragaee, S., Abdel-Aal, E.S.M., Noaman, M. 2006.
Antioxidant activity and nutrient composition of selected cereals for food use. Food Chemistry, 98: 32-38.

Rasmussen, L.B., Jorgensen, T., Perrild, H., Knudsen, N., Krejbjerg, A., Laurberg, P., Pedersen, I. B., Bjerbved, L., Ovesen, L. 2014. Mandatory iodine fortification of bread and salt increases iodine excretion in adults in Denmark - A 11-year followup study. Clinical Nutrition, 33:1033-1040.

IM, 2002. Dietary Reference Intake of Vitamin A, Vitamin K, Arsenic, Boron, Chromium, Copper, Iodine, Manganese, Molybdenum, Nickel, Silicon, Vanadium, and Zinc. Institute of Medicine, National Academy Press, Washington, D.C. USA.

Soetan, K.O., Olaiya, C.O., Oyewole, O.E. 2010. The importance of mineral elements for humans, domestic animals and plants: A review. African Journal of Food Science, 4: 200-220.

Thomson, B.M. 2009. Stability of added iodine in processed cereal foods. Food Additives and Contaminants, 26: 25-31.

Tuncel, N.B., Yilmaz, N., Kocabiyik, H., Uygur, A. 2014. The effect of infrared stabilized rice bran substitution on B vitamins, minerals and phytic acid content of pan breads: Part II. Journal of Cereal Science, 59: 162-166.

WHO and FAO, 2006. Guidelines for Food Fortification with Micronutrients. A. Lindsay, B. de Benoist, O. Dary and R. Hurrell (eds.) WHO Library Cataloguing -in-Publication Data. World Health Organization and Food and Agriculture Organization of the United Nations. ISBN 9241594012.

Zahoor, T. 2003. High Molecular Weight Glutenin Subunit Composition and Multivariate Analysis for Quality Traits of Common Wheats Grown in Pakistan. Ph.D. Thesis. University of Agriculture, Faisalabad, Pakistan.

Zimmermann, M.B., Boelaert, K. 2015. Iodine deficiency and thyroid disorders. The Lancet Diabetes \& Endocrinology, 3: 286-295.

Zimmermann, M.B. 2011. Iodine deficiency continues to plague Pakistan. ICCIDD. IDD Newsletter, 39: 1.11.2011.

Zimmermann, M.B. 2008. Iodine requirements and the risks and benefits of correcting iodine deficiency in populations. Journal of Trace Elements in Medicine and Biology, 22: 81-92. 